Canadian Journal of Higher Education Revue canadienne d'enseignement supérieur

Volume 47, No. 3, 2017, pages 76 - 100

\title{
Perceptions of the International Baccalau- reate (IB) in Canadian Universities
}

Saira Fitzgerald

Carleton University

\begin{abstract}
This article presents the results of the first Canada-wide survey on how university admissions personnel view the International Baccalaureate Diploma Program (IBDP) in relation to other curricula. The purpose of this study was twofold: (i) to move beyond anecdote and discover how Canada compares with universities in the UK and Australia/NZ, and (ii) to determine whether a dominant or hegemonic discourse surrounding the IBDP exists. Building on a small-scale pilot of perceptions in Ontario universities, the present study replicates two International Baccalaureate Organization studies (in the UK, 2003, and in Australia/NZ, in 2007) in the Canadian context. Results reveal a pattern of responses consistent with the previous studies-i.e., a confident positive general view, combined with uncertainty regarding specific aspects of the IBDP. Such widespread and consistent views suggest the existence of a dominant or hegemonic discourse surrounding the IBDP, constructing it as the standard of excellence in pre-tertiary education, which has important implications for publicly funded education in Canada.
\end{abstract}

\section{Résumé}

Cet article présente les résultats du premier sondage pancanadien portant sur la façon dont le personnel universitaire affecté aux admissions compare le programme du Baccalauréat international (BI) aux autres programmes. Le but de cette étude était double : (i) découvrir comment le Canada se compare réellement aux universités du Royaume-Uni et de l'Australie / NouvelleZélande, et (ii) déterminer s'il existe un discours dominant ou hégémonique 
entourant le BI. Élaborée à partir d'un petit échantillon de perceptions pris dans des universités ontariennes, la présente étude reproduit deux autres études de l'organisme Baccalauréat International (R.-U. en 2003 et Australie / N.-Z. en 2007) dans un contexte canadien. Les résultats révèlent un schéma de réponses cohérentes avec les études précédentes, à savoir, une vue générale positive combinée à une incertitude au sujet d'aspects précis du programme. De telles conceptions généralisées et constantes suggèrent l'existence d'un discours dominant ou hégémonique autour du BI, en l'échafaudant comme s'il s'agissait d'une norme d'excellence en enseignement préuniversitaire, ce qui a des implications importantes pour l'éducation publique au Canada.

\section{Introduction}

Universities in Canada are tripping over each other trying to entice IB students to come to our institutions. . . offering perks such as preferred residence rooms, priority enrollment in courses, special scholarships and full transfer credit to IB diploma holders ... the domino effect is sweeping the country. Those who are not developing IB friendly policies are losing out on great students in an increasingly competitive market for outstanding prospective students.

-Wendy Loat, admissions policy adviser, University of Toronto, and Chair, College University Recognition Task Force

Although the International Baccalaureate Organization's (IBO) flagship IB Diploma Program (IBDP) ${ }^{1}$ was originally designed to be offered in private international schools around the world for "students disadvantaged by having to live and study abroad" (Bagnall, 1994, p. 5), the past two decades have seen a growing adoption of the IBDP as an alternate curriculum within publicly funded schools in Canada, Australia, the United Kingdom, and the United States (see, e.g., Bagnall, 2010; W. Baker, 2014; Doherty, 2009; Tarc \& Beatty, 2012). One of the main reasons for this growth is the perception that the IBDP produces students who excel both academically and socially compared to students following other high school curricula.

In her analysis of IB discourse in Australia, Doherty (2009) argued that the appeal of the IB is linked to its portrayal as "all 'good news', with no whisper of critique" (p. 12). Such a positive view is evident in frequently repeated statements about the IBDP, referred to as "the Cadillac of college-prep programs" (Gehring, 2001), a "gold star" in secondary education (Byrd, Ellington, Gross, Jago, \& Stern, 2007), a "supertest" capable of transforming a failing education system (Matthews \& Hill, 2005), and an "international passport to higher education" (Blackburn, 1991). Furthermore, IBDP students are said to outperform students from other educational systems with respect to retention, degree completion, and securing the highest-paying jobs upon graduation (Halic, 2013; HESA, 2011; IBO, 2015). This high esteem is not restricted to the education domain, but has also been extended to other areas, such as linking the rise in property values to districts having IB schools (Spahn, 2001; Verneuille, 2011) and to lowering the likelihood of juveniles taking up cigarette smoking (Amuendo-Dorantes, Mach, \& Clapp, 2004; see also Cambridge, 2008). In one of the first doctoral dissertations to study the IBDP in Canada, 
Bagnall (1994) argued that "the IB is more than a qualification, it is a set of assumptions and a statement of the regard that society places on those who hold it" (p. 4). More recently, this idea of social and cultural capital has been expanded by linking the IBDP to the notion of "cosmopolitan capital" (Tarc, 2009; Weenink, 2008), thereby situating both the qualification and its holder in the global arena (Bagnall, 2010; Bunnell, 2010; Doherty, Luke, Shield, \& Hincksman, 2012; Gardner-McTaggart, 2016).

The view that the IBDP is a premier qualification for university admission can also be found on the websites of many high schools and universities, and in the media, as newspapers report on the program in various public schools around the country. As well, the IBO recently issued a press release titled "University Admissions Officers Suggest DP as Best Preparation for Workplace and University," which stated that this is the 1oth annual report showing such findings, meaning that the views of admissions officers have remained constant for over a decade (IBO, 2015).

However, running parallel to the discourse of IBDP praise is another recurring theme in the literature, that of a scarcity of empirical research to support these claims, both from scholars outside the IBO (e.g., Bunnell, 2008, 2014; Daly, 2012; Doherty, 2009; Doherty et al., 2012; Frank-Gemmill, 2013; Green \& Vignoles, 2012; Panich, 2001; Resnik, 2012; Tarc \& Beatty, 2012; Tarver, 2010; Whitehead, 2005) and from the organization's own research departments (Cambridge, 2002, 2008; Hayden \& Wong, 1997; IBO, 2003). For example, Bunnell (2010) remarked that it "seems strange after four decades of IB activity to comment upon the lack of empirical investigation" (p. 359). The main thrust of the argument focuses on selection bias in the research and also notes that successful performance in university could well be a result of the characteristics of the students rather than the IBDP curriculum.

Another consistent thread in the literature is that universities tend not to track students' performance based on curriculum, i.e., there are no systems in place to identify IB students and determine their level of achievement after they have been admitted. As such, when asked to comment on student performance, university admissions personnel routinely qualify their responses as being based on impressions or anecdotes rather than evidence (Barnes, 2004; Coates, Rosicka, \& MacMahon-Ball, 2007; Daly, 2012; Fitzgerald, 2015; Jenkins, 2003; Tarver, 2010). Nevertheless, in Canada, the IBDP has moved from relative obscurity in the 1990 s to being strongly endorsed as a premiere qualification by universities, schools, governments, and the media, with the number of IB schools the second highest in the world next to the US.

For these reasons, to better understand how university personnel viewed the IBDP in relation to other curricula, the IBO conducted two surveys of university personnel, one in the UK (Jenkins, 2003) and the second in Australia/New Zealand (Coates et al., 2007). Results from both showed that although the IBDP was viewed very favourably, knowledge about the program itself was either lacking or superficial, primarily based on anecdote or personal experience. No such survey has been conducted in Canada (except a smallscale pilot study in Ontario [Fitzgerald, 2015]). This paper presents the results of the first survey of university admissions personnel across Canada, replicating and extending the previous studies, and has a twofold purpose: (i) to move beyond anecdote and discover how Canada compares with universities in the UK and Australia/NZ and (ii) to determine whether a dominant or hegemonic discourse surrounding the IBDP exists. 


\section{Background of the IBDP in Canada}

The predominant view is that the introduction of the IBDP into North America came about as a result of dissatisfaction in the 1950s with the existing education system, which was seen as providing choice and flexibility at the expense of academic rigour (see, e.g., Bagnall, 1994; Bunnell, 2008; James, 2005; Mathews \& Hill, 2005; Matthews, 1989). A Nation at Risk, the 1983 U.S. report produced by President Reagan's National Commission on Excellence in Education, was highly critical of the education system, thus further reinforcing that view. This environment paved the way for the IBDP to be introduced into U.S. public schools:

It is not difficult to see why in such an educational climate some high schools concerned for academic excellence began to think of introducing an IB track. Because of the decentralization of the American system they were free to do so. (Peterson, 1987, p. 138)

While the growth of the IBDP in the US has been extensively discussed, the reason for the IBDP's rapid growth in Canada is less clear and seems to have taken the founders of the program themselves by surprise (Peterson, 1987, p. 143). Bagnall (1994) noted that in Canada there also existed a similar view that the standard of education was deteriorating (p. 116), on the basis of which the IBDP came to be considered as an alternative, but Walker (2005) stated that while public education in the US may have been in crisis, in Canada "the situation was different and the quality of public education was much better regarded" (p. 2), and that the reasons for adopting the IBDP had more to do with Canada's multicultural outlook and interest in an international education. Yet another view was offered by Fox (1998), who attributed the growth to the promotional campaign of the International Baccalaureate North America (IBNA) branch of the IBO, in New York (p. 73). Whatever the reason, the rapid growth of the IBDP in North America was unexpected and in fact led to tensions within the IBO (Bunnell, 2011; Mathews \& Hill, 2005).

\section{Prior Research on Perceptions of University Representatives}

Given the importance of university admission in the creation of the IBDP, it is notable that the first formal study of how university personnel view this qualification only took place in 2003, in the UK. Based on this, a second study followed in Australia/NZ in 2007. These two studies, both commissioned by the IBO, provided a first look at how the IBDP was viewed by universities in relation to other curricula and whether it was considered suitable preparation for university study. Although both studies stated they were neither evaluating nor validating the IBDP or actual student performance, they have been cited in IBO publications as evidence of IBDP students' university capabilities (e.g., IBO, 2007). As indicators of the global scope of IBDP research and acceptance, they have also frequently been cited by other researchers on the IB (e.g., O'Connor, 2011; Pook, 2009; Tarc \& Beatty, 2012). Using these studies as a basis, Daly (2012) and Tarver (2010) conducted surveys of U.S. college admissions personnel's perceptions and also discovered that while the IBDP was viewed very favourably by admissions personnel, knowledge about the program was superficial or lacking. A small-scale pilot study of perceptions in Ontario universities, the results of which form the basis of the present study, showed a similar trend. 


\section{Theoretical and Methodological Framework}

The wider research project, of which the present study is a part, employs the discourse historical approach (DHA) combined with corpus linguistics (CL) to examine IBDP discourse as it occurs in different public domains (see Baker et al., 2008, for details on the "synergy" between these two methodologies). As a branch of Critical Discourse Analysis (CDA), the DHA views language as social practice and the context of language use to be crucial (Fairclough \& Wodak, 1997). One of the main features that distinguishes the DHA from other CDA approaches is its integration of multiple genres surrounding a particular issue, and its focus on the historical dimension of that issue. By contextualizing discourse socially, institutionally and historically, the DHA helps to identify "particular discursive strategies that serve to present the arguments of an individual or a group either positively or negatively" (Richardson \& Wodak, 2009, p. 255).

The success of the IBDP depends on its acceptance by universities as a suitable qualification for admission (Blackburn, 1991), which in turn depends on acceptance by schools, parents, students, provincial governments, and the media. For this reason, the IBO has produced numerous publications, brochures, conference presentations, and workshops to promote greater understanding of the IBDP in relation to other curricula. As this information gets picked up and repeated uncritically in various fora, a "common language" (Daly, 2012, p. 8) or hegemonic discourse of the IBDP starts to form, perpetuating a positive view of the curriculum across domains. This suggests a dialectical discursive construction that is shaped by, but also shapes, the social structures in which the IB operates (Fairclough \& Wodak, 1997). Through the analysis of IB-related texts from different contexts, we may discover linguistic patterns involved in the construction of discourses surrounding the IBDP as a preferred qualification. Examining "multiple genres and multiple public spaces" (Wodak, 2001, p. 70) can allow for a broader understanding of how the IBDP is discursively represented in Canada, with the view that "language is not powerful on its own-it gains power by the use powerful people make of it" (Wodak, 2007, p. 209). However, as Baker (2005) argued, the first step is to determine whether a dominant or hegemonic discourse does in fact exist, rather than it simply being a reflection of researcher bias. One possible method is to consult a representative set of people by means of surveys and focus groups (Baker, 2005).

\section{Method}

The survey results reported in this article form the first phase of a three-phase mixed method study. Based on the results of a pilot study of Ontario universities, the survey was expanded to include universities from all 10 provinces. Although the original study design consisted of survey responses followed by interviews with interested participants, the lack of uptake (only three individuals expressed an interest), combined with the time required to obtain additional Research Ethics Board (REB) clearance from each institution, made the interview stage not feasible. For this reason, the open-ended comments provided by 63 participants are used to supplement the quantitative survey data.

\section{Instrument: Online Survey}

The survey questions from the UK and Australia/NZ surveys were adapted for the Canadian context and consisted of three main types: checklist, Likert-scale, and open- 
ended (Brown, 2001). These were grouped into five broad categories: (i) background information about the respondent; (ii) general information about university applications; (iii) specific information about IBDP applications; (iv) comparison of the IBDP to other curricula; and (v) an open-ended question and additional comments. A negative response to any of the four questions at the start terminated the survey: informed consent, privacy statement, background information, and application assessment. The substantive questions were programmed to be optional; respondents were not required to provide answers to questions on one page before advancing to the next. The survey was field tested and revised before it was posted online.

\section{Participants}

Universities were selected from the AUCC (Universities Canada) website for each province to include only those that are English-medium, and to exclude any affiliations (colleges or religion-based) as well as specialized institutions. From a total of 55 universities that fulfilled these criteria, 54 were contacted regarding REB clearance procedures. Contact information for one university could not be located, but it managed to participate in the survey and is included in the total number. Of the 54 contacted, final REB approval was granted by 48 . Approximately 550 individual email invitations were sent to admissions personnel at these 48 institutions, using contact details obtained from institutional websites. Of these, 78 participants from 40 institutions responded. In order to preserve the anonymity of institutions, they have been grouped regionally (see Figure 1):

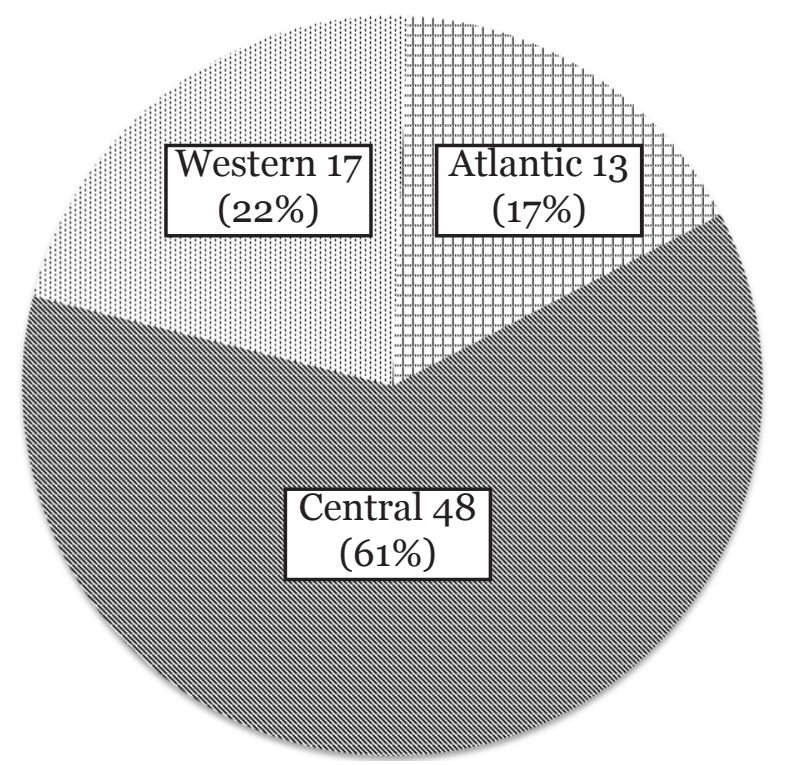

Figure 1. Regional representation of participants $(\mathrm{n}=78)$

Atlantic (four provinces, eight universities, $n=13$ ); Central (two provinces, 16 universities, $n=48$ ); Western (four provinces, 16 universities, $n=17$ ).

The target population for this study was specific and deliberately chosen, i.e., a purposive sample (Vogt, 2007). Unlike the UK and Australia/NZ studies, ${ }^{2}$ the present study targeted admissions officers whose duties include regular evaluation and interpretation 
of IB documents. To ensure that the sample remained specific, the survey was designed to terminate if respondents answered "No" to the question "Do you assess admissions applications from high school students?" Thus, although the sample size was small compared to both previous studies, this limitation is mitigated by the $100 \%$ contact respondents have with IB students, allowing a more reliable picture to emerge.

Of the 78 respondents, 20 (26\%) had been in their position for more than 10 years, 24 (31\%) for 5 to 10 years, and $33(42 \%)$ for fewer than 5 years. One respondent provided no information for this question.

\section{Findings}

Survey results have been grouped into four categories: (i) background and procedural information; (ii) comparison of the IBDP to other curricula; (iii) open-ended questions; and (iv) additional comments.

\section{Background and Procedural Information}

Respondents were first asked about the origin of the applications they assessed, to determine bases for the comparison of different curricula. All 78 respondents (100\%) evaluated applications originating from their home province, out of their home province but within Canada, the United States, and other international systems. To determine the proportion of IB applications in relation to other types of applications (CEGEP, A Levels, U.S. high school, other international), respondents were asked to indicate the percentage of each type they had evaluated over the previous year, according to the following scale: (i) less than 5\%; (ii) $5-10 \%$; (iii) $10-15 \%$; (iv) more than $15 \%$; and (v) N/A. A total of 78 responses were received (see Figure 2).

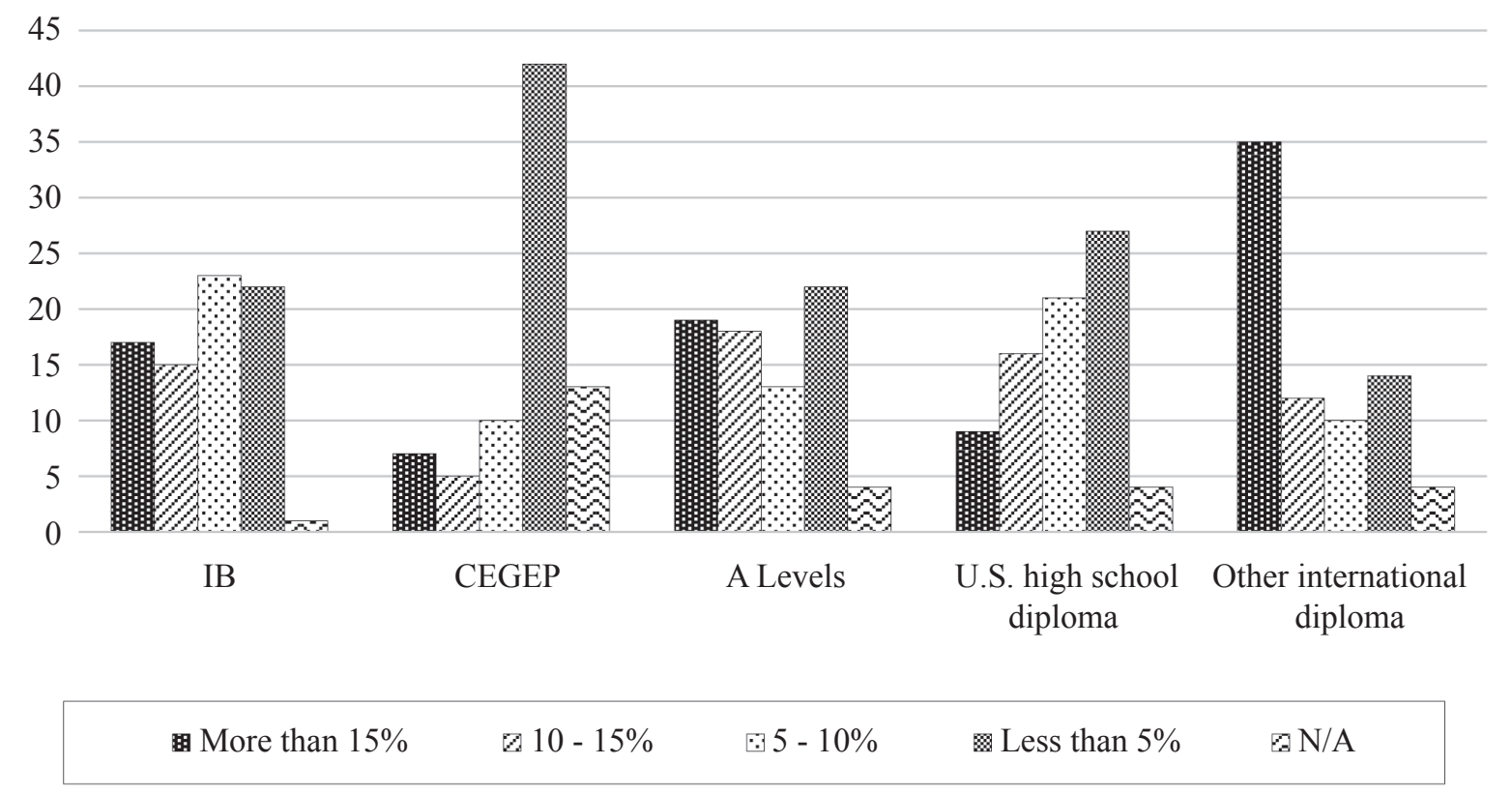

Figure 2. Percentage of applications assessed by origin $(n=78)$. 


\section{Comparison of the IBDP to Other Curricula}

Nine Likert-scale questions were adapted from the Australia/NZ study (Coates et al., p. 42), deliberately retaining the positive bias evident in that study. The questions asked respondents about specific aspects of the IBDP in relation to their own provincial high school curriculum, other Canadian high school curricula, U.S. high school curricula, A Levels (UK high schools), and other international curricula. Each of the statements required a response ranging from "strongly agree" to "strongly disagree" or "cannot say." Although the responses to these substantive questions showed a similar trend as the Ontario pilot study, greater variation was evident among admissions officers across universities.

(i) The IB is more challenging than... As shown in Figure 3, the overwhelming majority of respondents agreed that the IB was more challenging than their provincial curriculum (88\%), all other Canadian high school curricula (82\%), and U.S. high school curricula (79\%). Only two respondents somewhat disagreed, and seven neither agreed nor disagreed or could not say with respect to their provincial curricula. For other Canadian and U.S. high school curricula, no respondents disagreed, whereas 18\% (Canada) and 21\% (US) neither agreed nor disagreed or could not say. Responses diverged more with respect to A Levels (59\%) and other international curricula (41\%), where a much larger percentage of respondents neither agreed nor disagreed or were unable to say. Two respondents provided no information for other international curricula.

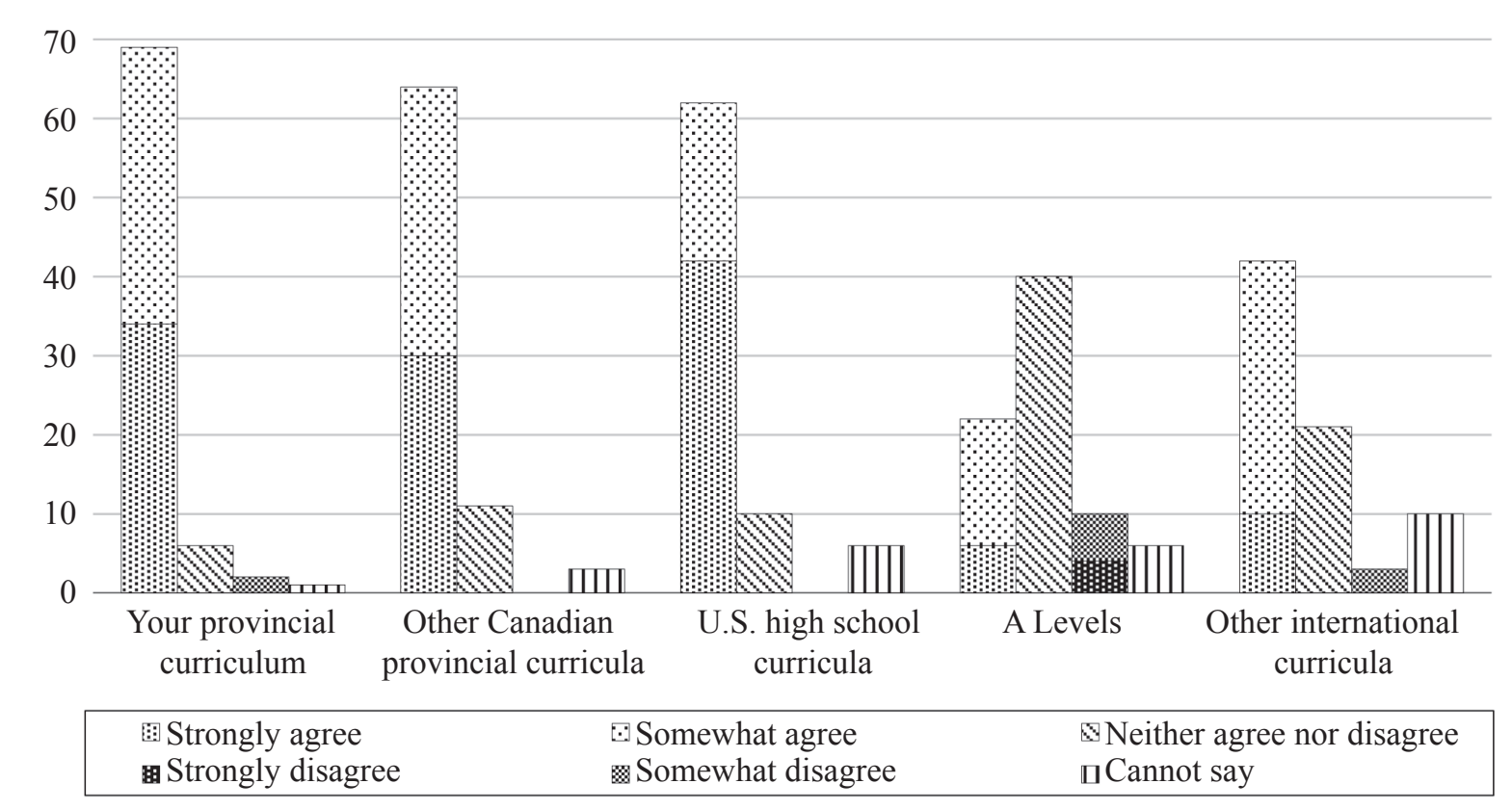

Figure 3. Comparison of challenge $(n=78)$.

(ii) The IB prepares students better for university studies than... As shown in Figure 4, the majority of respondents (79\%) again agreed that the IB better prepares students for university study than all Canadian and U.S. high school curricula. Four disagreed in terms of provincial and two in terms of Canadian, and one somewhat disagreed with respect to U.S. high school curricula. Twelve respondents (16\%) for provincial, 14 
(18\%) for other Canadian, and 15 (20\%) for U.S. high school curricula neither agreed nor disagreed or could not say. Responses again diverged with respect to A Levels (55\%) and other international curricula (44\%), where a larger percentage of respondents neither agreed nor disagreed or were unable to say. One respondent provided no information for U.S. high school curricula or A Levels.

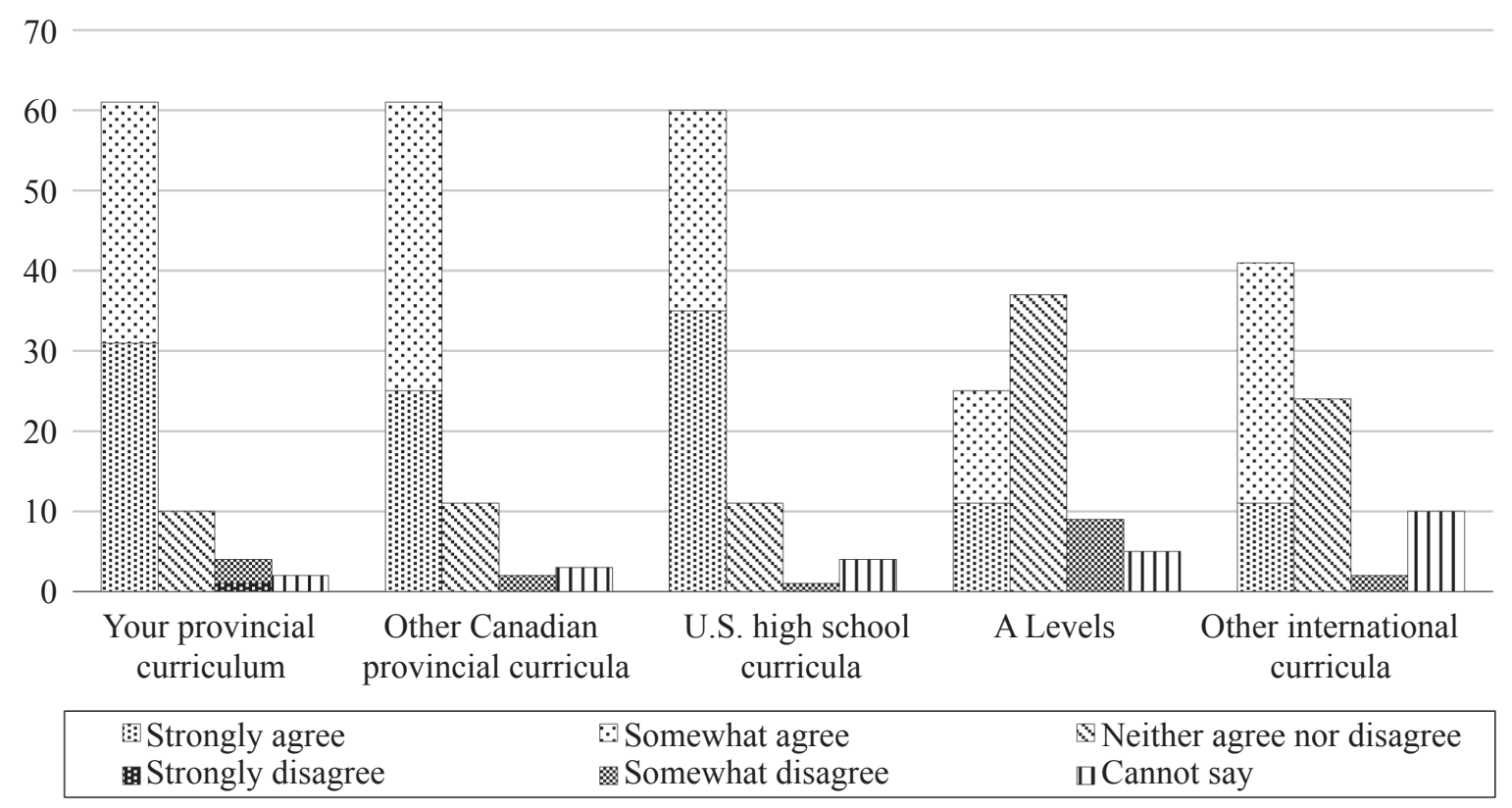

Figure 4. Comparison of preparation for university studies $(n=77)$.

(iii) IB students make an easier transition to university than students who have taken... As shown in Figure 5, 53\% of the respondents agreed that IB students make an easier transition to university than students from their provincial and U.S. high school curricula, whereas 54\% agreed with respect to other Canadian high school curricula. Seven (9\%) disagreed with respect to their provincial curricula, five (6\%) disagreed in terms of other Canadian curricula, and four (5\%) disagreed regarding U.S. high school curricula. Thirty respondents (38\%) for provincial, 31 (40\%) for other Canadian, and 33 (42\%) for U.S. high school curricula neither agreed nor disagreed or could not say. With respect to A Levels and other international curricula, the majority of respondents $(69 \%$ and $53 \%$, respectively) neither agreed nor disagreed or were unable to say. One respondent provided no information for A Levels.

(iv) IB students are more capable of independent research than students who have taken... As shown in Figure 6, half the respondents (50\%) agreed that IB students are more capable of independent research than students from their provincial curricula, whereas $47 \%$ agreed with respect to other Canadian curricula and $49 \%$ with U.S. high school curricula. Only four respondents disagreed for all three, whereas $45-47 \%$ neither agreed nor disagreed or could not say. Regarding A Levels and other international curricula, again the majority of respondents (68\% and 59\%, respectively) neither agreed nor disagreed or were unable to say. Two respondents provided no information for provincial curricula and A Levels. 


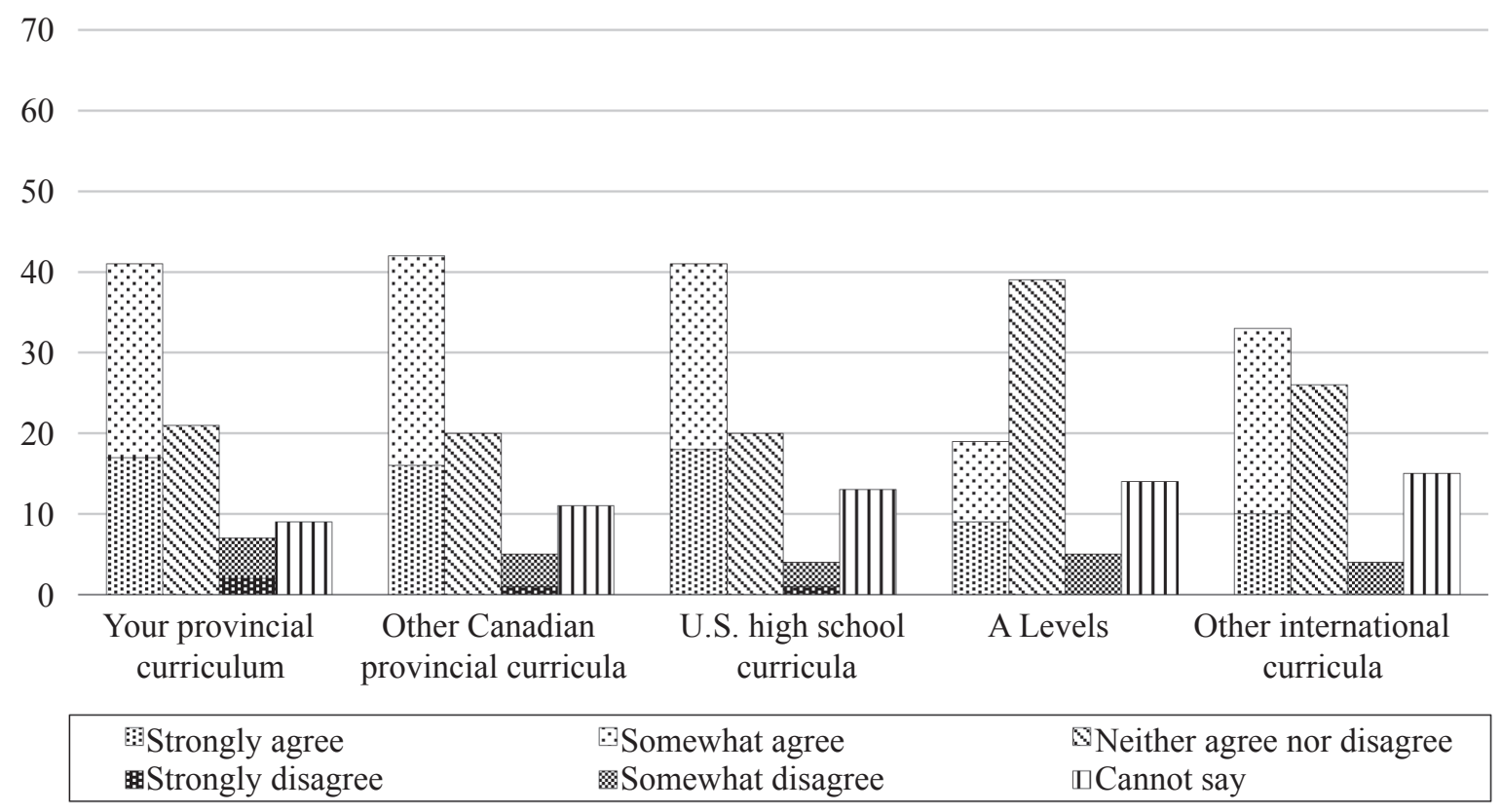

Figure 5. Comparison of transition to university $(n=78)$.

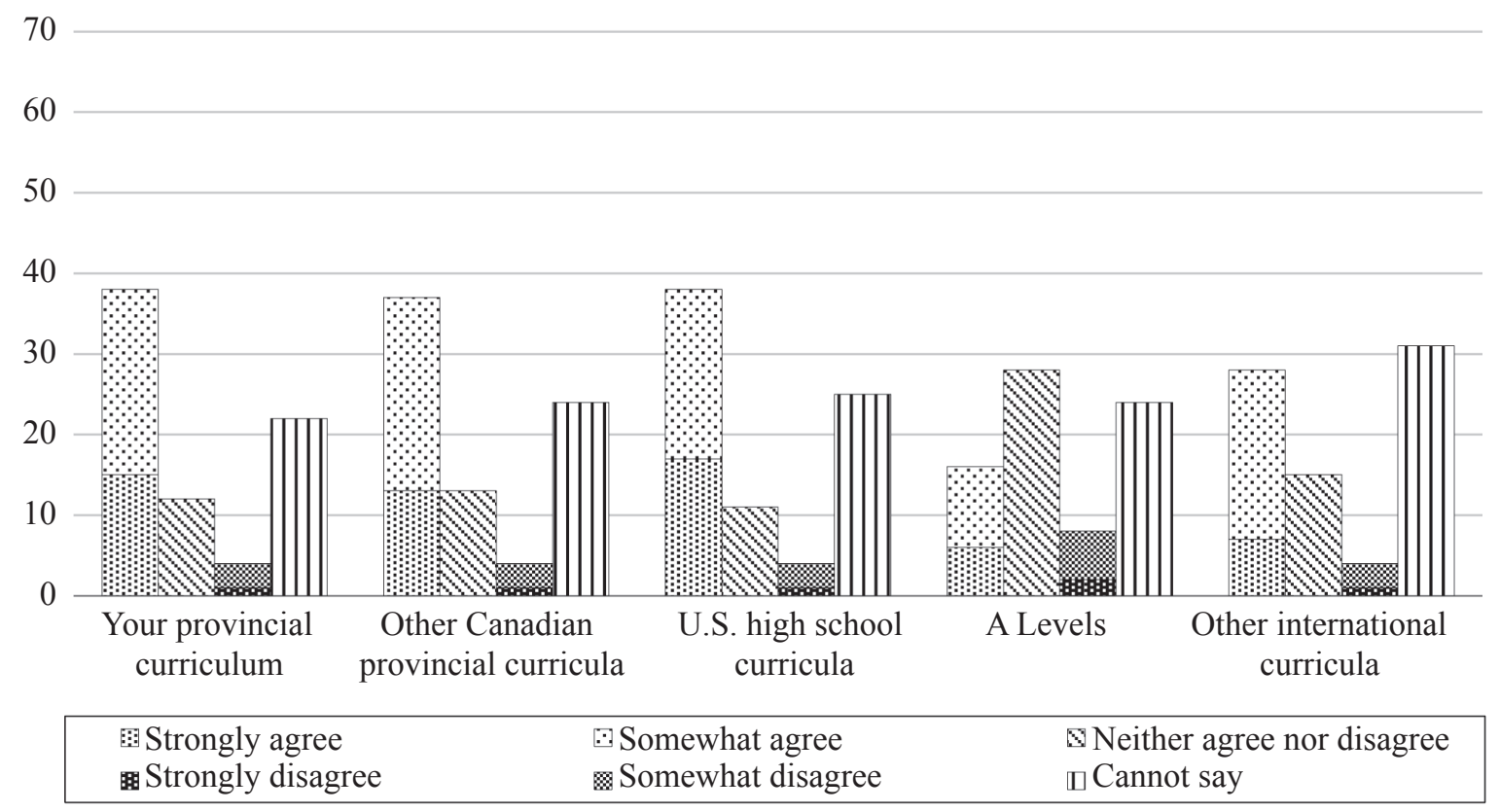

Figure 6. Comparison of independent research capability $(n=78)$.

(v) IB students have better research skills than students who have taken... As shown in Figure 7, less than half of the respondents agreed that IB students have better research skills than students who had taken their provincial (48\%), other Canadian (45\%), or U.S. (42\%) high school curricula. Only three respondents disagreed for all three, whereas 37 (48\%) respondents for provincial, 39 (51\%) for other Canadian, and 41 (54\%) 
for U.S. high school curricula neither agreed nor disagreed or could not say. Regarding A Levels and other international curricula, the majority of respondents (70\% and 64\%, respectively) neither agreed nor disagreed or could not say. One respondent provided no information for U.S. high school and other international curricula.

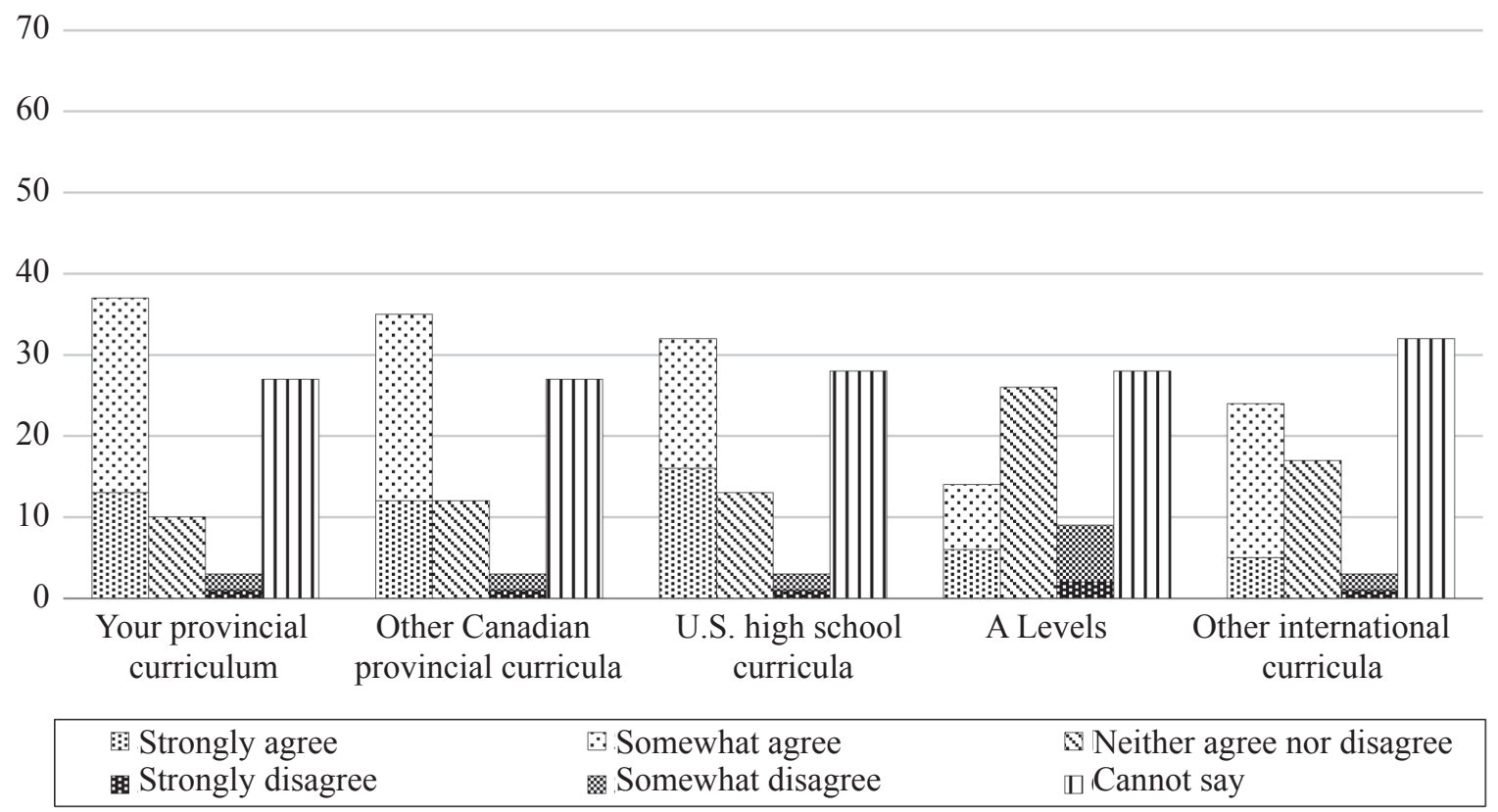

Figure 7. Comparison of research skills $(n=77)$.

(vi) IB students have better written communication skills than students who have taken... As shown in Figure 8, slightly more than half of the respondents (53\%) agreed that IB students have better written communication skills than students from their provincial curricula, half (50\%) agreed for other Canadian curricula, and less than half (46\%) for U.S. high school curricula. Only two respondents disagreed regarding provincial and other Canadian, and one disagreed for U.S. high school curricula. Thirtyfive (45\%) respondents for provincial, 37 (47\%) for other Canadian, and 41 (53\%) for U.S. high school curricula neither agreed nor disagreed or were unable to say. Again, with respect to A Levels and other international curricula, the majority of respondents $(70 \%$ and $60 \%$, respectively) neither agreed nor disagreed or could not say. One respondent provided no information for A Levels and other international curricula.

(vii) IB students have better oral communication skills than students who have taken... As shown in Figure 9, the majority of respondents (68-69\%) either could not say or neither agreed nor disagreed that IB students have better oral communication skills than students from all Canadian and U.S. high school curricula. Only five respondents disagreed with respect to Canadian and four with respect to US high school curricula, while 20 (26\%) agreed for all three. Regarding A Levels and other international curricula, the majority ( $81 \%$ and $74 \%$, respectively) neither agreed nor disagreed or could not say. One respondent provided no information for U.S. high school curricula. 


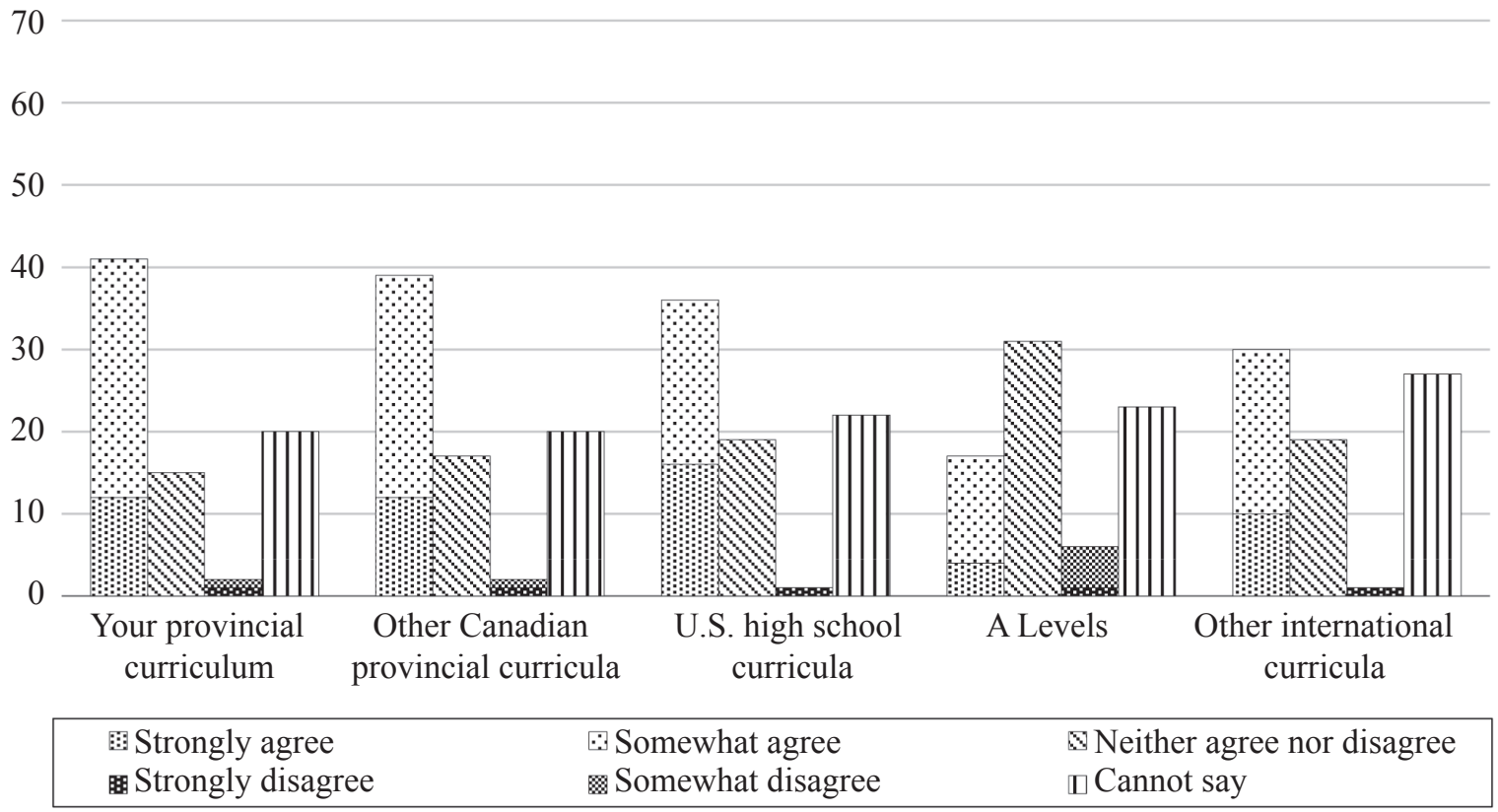

Figure 8. Comparison of written communication skills $(n=78)$.

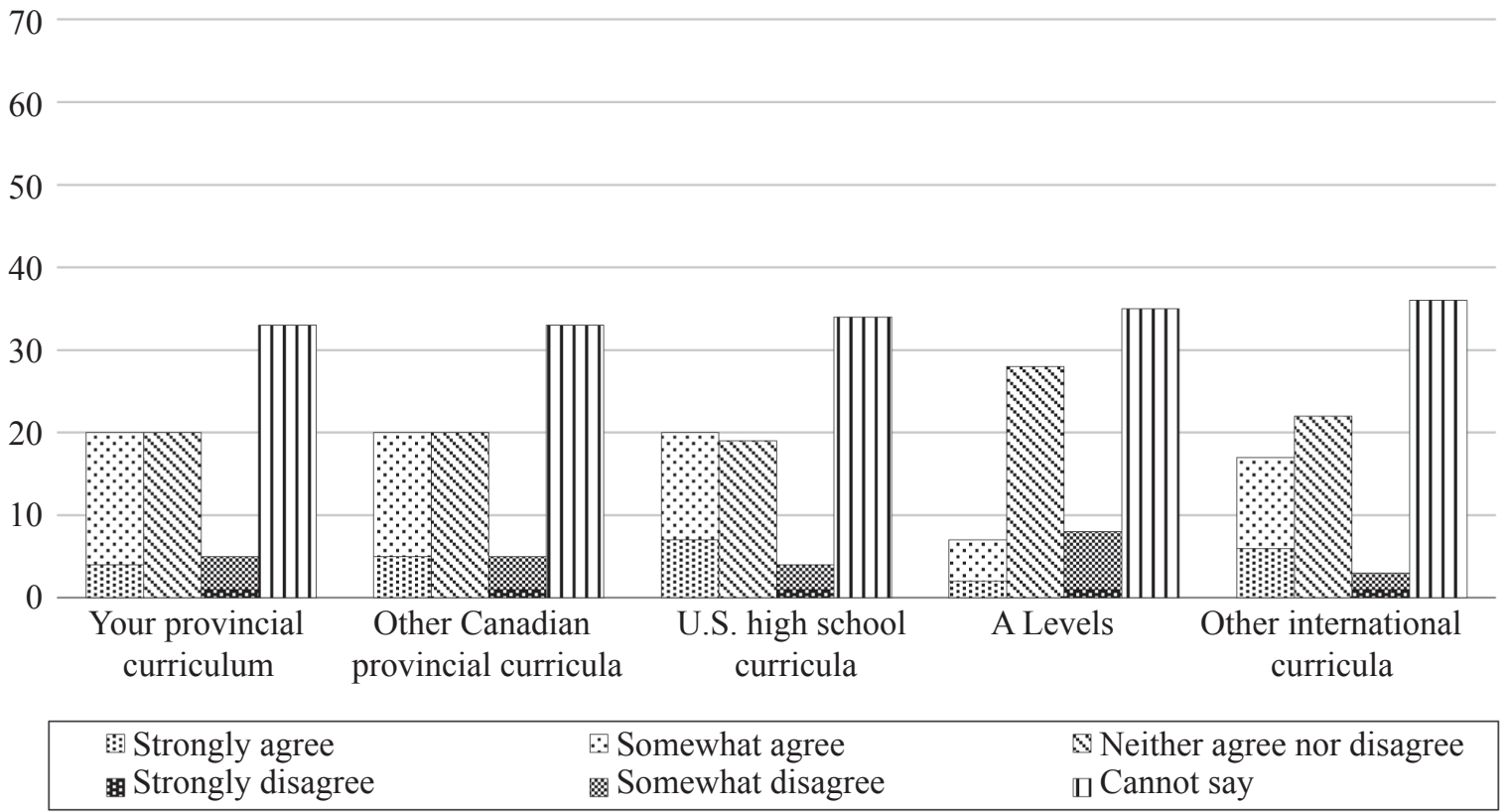

Figure 9. Comparison of oral communication skills $(n=78)$.

(viii) IB students are more active in university life than students who have taken... As shown in Figure 10, the overwhelming majority of respondents (81-88\%) either could not say or neither agreed nor disagreed that IB students were more active in university life than students from any other curriculum. Nine respondents agreed with respect to provincial and seven for other Canadian curricula. Six respondents agreed in terms of U.S., A Levels, and other international curricula. One respondent provided no information for other Canadian and U.S. high school curricula. 


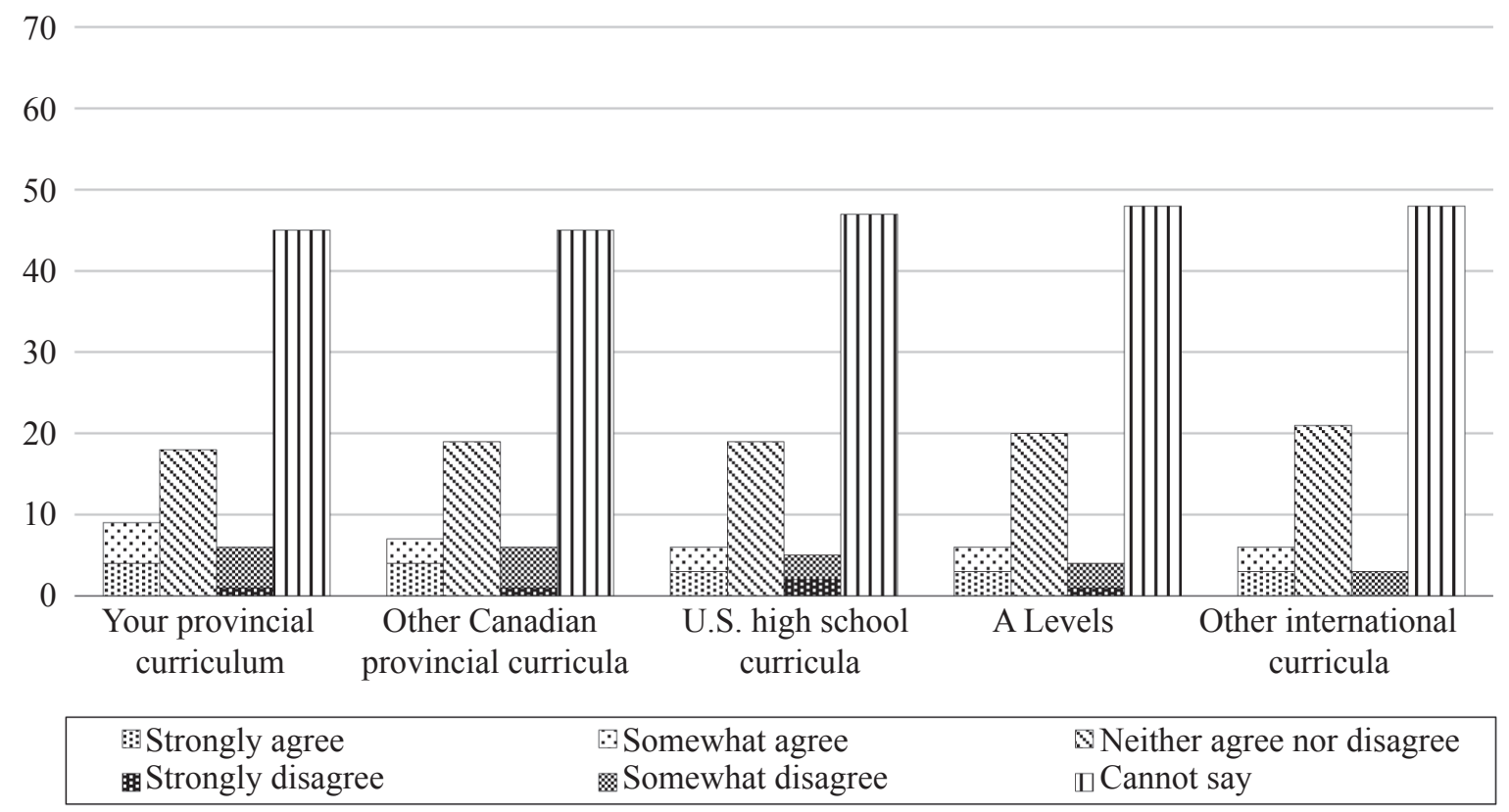

Figure 10. Comparison of activeness in university life $(n=78)$.

(ix) IB students are better problem solvers than students who have taken... As shown in Figure 11, the majority of respondents (68-69\%) either could not say or neither agreed nor disagreed that IB students were better problem solvers than students from all Canadian and U.S. high school curricula. The number was much larger for A Levels and other international curricula, at $83 \%$ and $77 \%$, respectively. Twenty-four respondents (31\%) agreed that IB students were better problem solvers than students from their provincial curricula, while 23 (29\%) agreed with respect to other Canadian and U.S. high school curricula. The numbers dropped noticeably for A Levels (nine, 12\%) and other international curricula $(16,21 \%)$. One respondent provided no information for other international curricula.

70

60

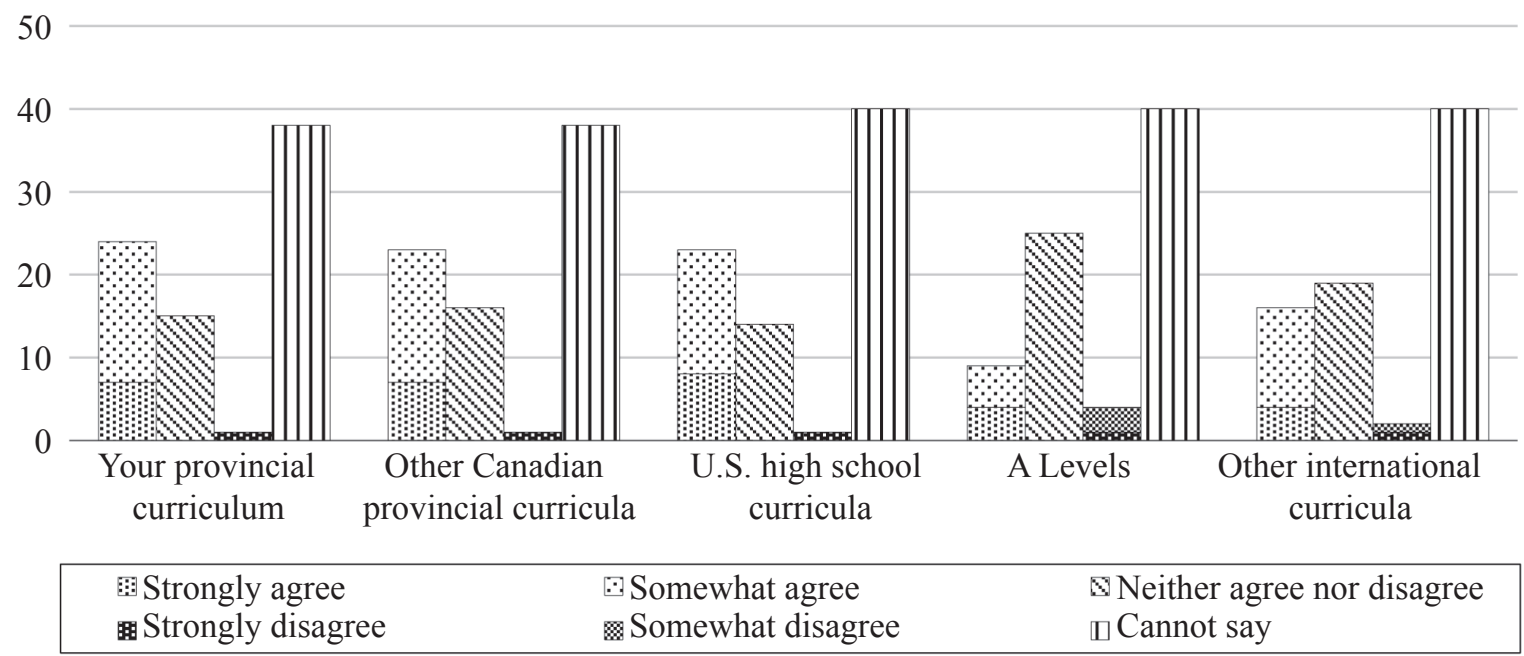

Figure 11. Comparison of problem-solving abilities $(n=78)$. 
(x) Overall opinion of IBDP versus Canadian high school. Respondents were asked whether, in their opinion, Canadian students graduating with an IB diploma had more advantages than their peers graduating with provincial certificates. Sixty-four percent replied in the affirmative (Figure 12).

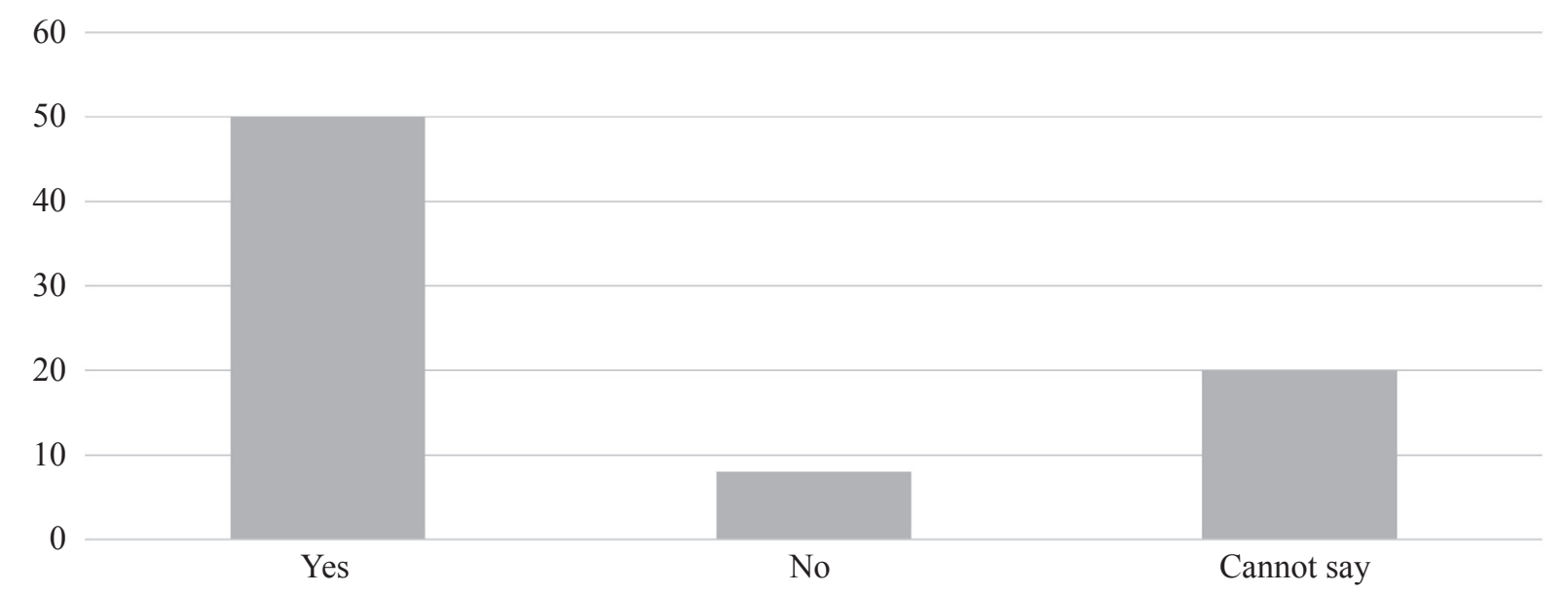

Figure 12. Opinion of IBDP advantage $(n=78)$.

(xi) Sources of information. Respondents were asked to indicate the sources of their information about the IB (see Figure 13). The majority of respondents (81\%) indicated two main sources: IBO public webpages and internal documents generated by their unit. The second major source indicated was the respondent's own institutional website (68\%), followed by the institution's calendar (64\%). Other sources were external information sessions (47\%) and IBO secure webpages (37\%). Nine respondents indicated other sources, in the free text box provided, which included information from NARIC (the National Academic Recognition Information Centre), official transcripts and guides, governmental and other institutional research, IB students, schools, counsellors, scholarly publications, and other colleagues.

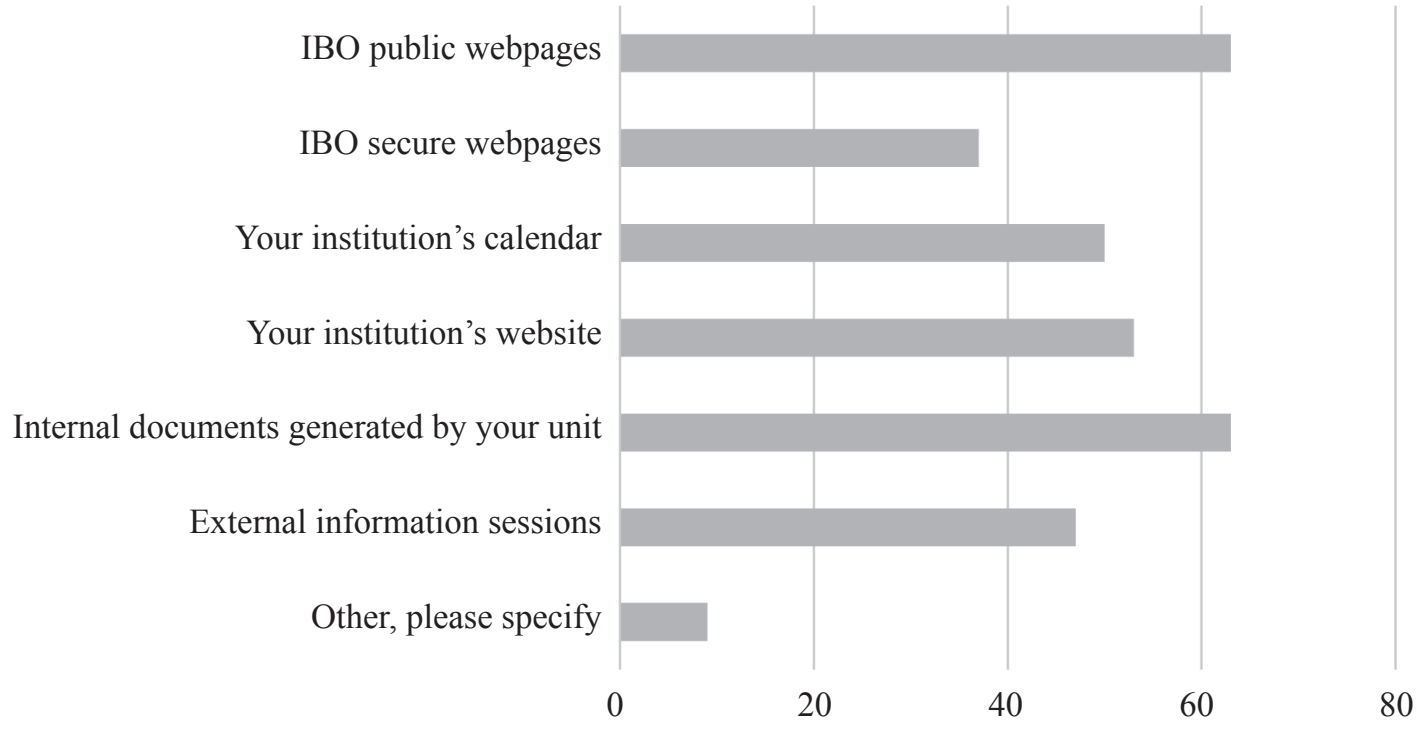

Figure 13. Sources of IB information $(n=78)$. 


\section{Open-Ended Questions.}

Respondents were asked to provide their overall view of the IB diploma. A total of 63 responses were submitted, which were coded according to seven broad themes that emerged (see Table 1).

Table 1. Summary of open-ended responses $(n=63)$

Theme

1. Rigorous (challenging, strong, etc.) curriculum

2. Prepares for university

3. Comparative statements $(19+/ 7-)$

4. Good students (up for the challenge)

5. Transfer credit

6. Well monitored (grades reliable, consistent teaching, etc.)

7. Available worldwide/widely recognized
Number of Responses

$47(75 \%)$

$26(41 \%)$

$26(41 \%)$

$15(24 \%)$

$12(19 \%)$

$11(17 \%)$

$6(10 \%)$

Due to the open-ended nature of the question, each response contained more than one theme. All but three expressed a favourable view of the IBDP, and only one stated that the IBDP was the "same quality as a provincial credential." Forty-seven (75\%) referred to the IBDP positively (e.g., as "rigorous," "strong," "challenging," "excellent," "solid," "well rounded," "enriched"), while 26 (41\%) noted specifically that the IBDP prepares students well for university/post-secondary studies. Seventeen (27\%) commented on the IB system of education as being widely recognized, well monitored by the IBO, consistent, standardized, easier for admissions officers to understand, and providing "realistic grades" that have not experienced the "massive grade inflation" seen in the public system. One respondent commented: "I tend to feel more confident about an applicant's potential success at our institution if they've completed the IB diploma with strong results." However, two remarked that IB grades are translated inconsistently, and one stated that IB predicted grades were "not standardized internationally" and were "unfortunately too frequently inaccurate."

Twenty-six (41\%) commented on the IBDP in relation to other curricula. Nineteen of these comments were positive, indicating that the IBDP was better, more rigorous, a more advanced curriculum, provided students with additional preparation, and was a better indicator of student success in postsecondary education. One respondent commented: "I believe it is the strongest curriculum that we receive in decent numbers." However, seven of the 26 respondents explained that they did not believe the IBDP to be better than provincial curricula or that all IB students are successful, saying: "it is more dependent on the student than the curriculum that they are studying," as well as noting "many other intersectional factors that come into play when determining which students will and which students will not be successful in the post-secondary system." Fifteen respondents commented on students being ready and academically strong to take on the challenge of extra work. 
Another theme that emerged dealt with awarding transfer credits for IBDP courses, commented on by 12 (19\%) respondents. Most (10) referred to this dimension of the IBDP positively (e.g., bonus, advantage, better option), with one respondent stating that "a full year of advanced standing" is offered to IBDP students coming to their institution. However, two stated that the IBDP "should not be used to grant transfer credits" and that too much emphasis was being placed on this aspect of the program.

\section{Additional Comments}

At the end of the survey, respondents were provided with an opportunity to comment on the survey as a whole. A total of 22 comments were received. Of these, six expressed uncertainty about the questions and whether admissions officers were able to answer questions relating to university performance or research and problem-solving skills, since none of these are measured following admission, and therefore respondents would not have the necessary information. Four stated that they found it difficult to compare different curricula, since there was a great deal of variation not only across provinces but also internationally. Three commented on the nature of the questions and the possible bias, stating, "the assumption that all IB students are more committed is not accurate," and "[s]trong, well-rounded students can come from any background or curriculum." One respondent noted:

[a]s an international admissions officer, I welcome the standardization of the IB program as it makes my job easier. I can be confident that the official transcript is an accurate representation of the applicants [sic] academic background and competency. This is not always the case with local curricula and inconsistent educational systems.

The remaining eight comments related to policies and procedures governing IBDP transfer credits and English language requirements at particular institutions.

\section{Discussion}

The purpose of this study was twofold: (i) to move beyond anecdote and discover how Canada compares with universities in the UK and Australia/NZ, and (ii) to determine whether a dominant or hegemonic discourse surrounding the IBDP exists. One thing noticeable in all the surveys is the consistency of responses regarding the IBDP curriculum, even though participants commented that information is not available to admissions officers and that there is an absence of empirical evidence, notably of studies tracking student performance. Both the UK and the Australia/NZ surveys reported an overall positive view of the IBDP and, at the same time, a lack of knowledge as to what the program actually was. Participants commented that they did not possess knowledge or information about the program or the relative performance of IB students. The same trend was reported in the two small-scale U.S. studies on admissions personnel: an overall positive view of the program (It is a very rigorous and challenging program) and the students (I think the students in the IB program are really smart), followed by statements regarding knowledge about the program (I do not have enough familiarity with the IBDP to comment fully or pass judgement) or student performance (we do not track students once they are admitted so cannot 
comment on student performance). The uniformity of responses regarding the IB has been commented on by a number of researchers, notably one who attested to being "astonished" by the similarities, given the open-ended nature of the questions (Mayer, 2006). This trend was echoed in the Ontario pilot study, where a unanimous overall positive view gave way to uncertainty regarding specific aspects of the program. The same trend is also evident in the present study, where the overall perception of the IBDP is positive, seeing it as more challenging and better preparation for university than any Canadian or U.S. high school curriculum. However, the view becomes more tentative and nuanced when specific aspects of the IBDP are considered. Comments by participants also state that such details on student performance are not available to admissions officers, since these different skills (such as research, writing, and oral expression) are not measured following admission. Interestingly, as Figure 14 shows, there appears to be slightly more agreement regarding transition to university and written communication skills. Since the knowledge base remains just as restricted as for other categories, this may have more to do with what respondents have heard about the IBDP. The "incremental effect of discourse" (Baker, 2006, pp. 13-14) becomes evident in how repeated phrases influence our perceptions and then often get reproduced, further contributing to the discourse. In just such a way, an IBDP image is built on assumptions and the impressions of others in the absence of rigorous research (Conner, 2008; May \& Perna, 2011), revealing an IB ideology, or "IBeology"-i.e., everyone says that the IBDP is better and that IB students are obviously smart, but at the same time also say they do not know much about the program or about actual student performance.

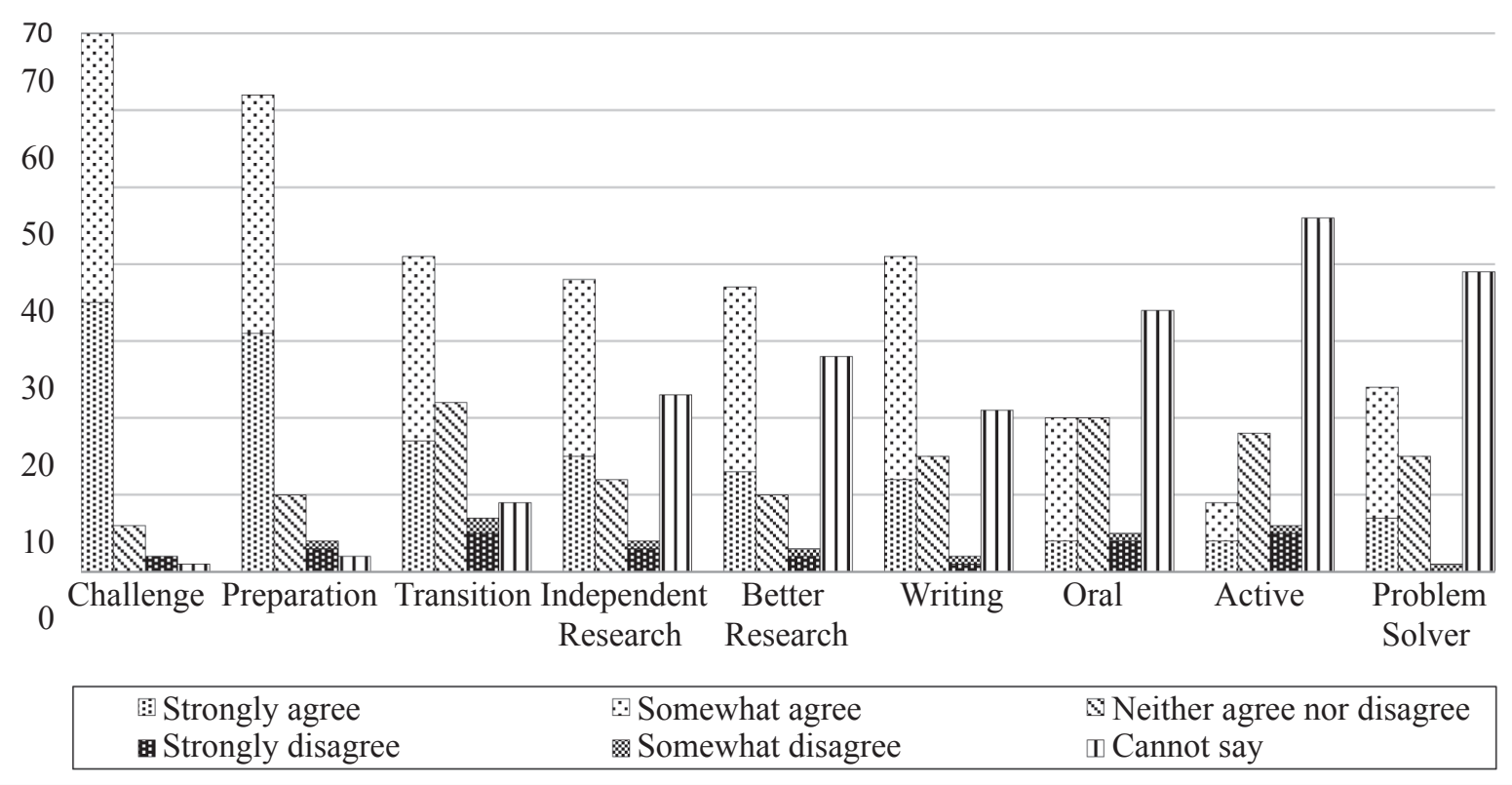

Figure 14. Summary of open-ended responses $(n=63)$.

The consistent pattern evident in these different surveys of the IBDP suggests that a hegemonic discourse about the IBDP does exist, one that has become naturalized through repetition (Baker, 2010, p. 124) and has come to be taken for granted in the public domain, resulting in a stereotypical image. A number of researchers (e.g., Conner, 2008) have discussed how the media and other stakeholders (such as education administrators, 
policy makers, parents, and students) play a role in shaping and conveying this impression. In this way, the IBDP as a premiere qualification for university study and also for "the workplace" (IBO, 2015) is discursively constructed-i.e., the image is collectively coconstructed by different segments of society such that the IBDP becomes reified as a superior curriculum. This type of perception can be seen in the remarks made by the 1983 Director of Curriculum of Alberta Education:

It's a known program. I believe the program has rigor, because of its acceptance by universities around the world. There is no question in my mind [emphasis added] that the student who graduates with an IB Diploma has had a more rigorous training than the student in Alberta who matriculates. It reflects the higher level examinations. (cited in Rowell, 1983, p. 55)

Such certainty about the superiority of the IBDP in relation to other curricula is formed despite issues of self-selection and differences amongst students and schools. ${ }^{3}$ Perna et al. (2011) argued that the IB program at one school is not the same as the IB program at another school, which therefore raises questions about exactly what is being described in terms of the effects of the program (p. 26). Alec Peterson, founder of the IBDP, has also stated that IB schools in North America have little in common (1987, p. 152).

As Fairclough and Wodak (1997) argued, the relationship between a discursive event and the social structures that frame it is dialectical-i.e., the event is shaped by, but also shapes, the social structures. Discourses surrounding the IBDP are often quite similar, in that the IBDP is regularly presented as the natural solution to the "problem" of moribund educational systems ill-suited for a competitive globalized world. Against this "discourse of derision" (Parker, 2011, p. 493), public/state schools and the local curriculum are relegated to an inferior status (Resnik, 2012). Such a perception was found in the surveys of university personnel in the UK, Australia/NZ, the US, Ontario, and, as this study shows, across Canada.

An important aspect of IBDP discourse revealed by respondent comments in the survey is the construction of "IB students" as a homogeneous group (IB students do well academically) and as having particular qualities (IB students are academically able, well rounded, enriched, take on challenge, work harder, are high performing). ${ }^{4}$ Qualities attributed to IB students are not always mentioned explicitly but draw on the "IB" label to bring related attributes to the fore. In constructing this type of in-group, there is a correlative out-group construction. Referring to "IB students" as a homogeneous group with associated characteristics is a discursive strategy that draws on evaluative binary terms and results in a polarization of positive and negative values attributed to the in-group and out-group. The repeated presentation of IB students as embodying such qualities implies that other, nonIB, students lack them. Creating this exclusive "us" marginalizes those outside the group, using a positive-us/negative-other discourse strategy (Reisigl \& Wodak, 2001).

A mythology of "the IB" seems to have been created, where the "IB World School" educates the "IB Learner," who embodies qualities described in the "IB Learner Profile" (Bunnell, 2010). Through such reification, "the IB" becomes a value-laden term associated with all the qualities discursively linked to it, thereby giving it a positive semantic/ discourse prosody or aura (see, e.g., Stubbs, 2001). As the term becomes reified and more naturalized, it acts as a shortcut, "priming" (Hoey, 2005) us to unconsciously attribute these associated qualities. 


\section{Limitations of the Study}

The sample, while purposive, is limited in that only English-medium universities were selected and each required REB clearance before recruitment of participants could take place. In some cases, after lengthy REB processes were complete and the survey was deployed, no responses were returned. The survey questions retained the positive skew of the Australia/NZ survey from which they were adapted. This bias was remarked on by the Carleton REB as well as by one of the survey participants. Since the present study was replicating the previous studies, it was important to retain the positive skew in order to see how Canadian university personnel would respond. Furthermore, only descriptive statistical methods were used in the interest of consistency, thereby limiting additional insights.

\section{Conclusion}

This article presented the results of the first phase of an ongoing research project on IB discourse in Canada. Based on two previous studies conducted in the UK and Australia/ $\mathrm{NZ}$, and building on a small-scale pilot study in Ontario, this study aimed to explore the perceptions of admissions officers in Canadian universities across 10 provinces. It was designed to replicate and extend the two previous studies but was adapted for the Canadian context. Although the sample was smaller than the two IBO-commissioned surveys, the purposive aspect of the sample and the participation of universities from all 10 provinces provided important first data on how the IBDP is viewed by Canadian admissions officers.

The results show a similar trend to previous studies, with a highly positive disposition towards the IBDP, particularly when compared to the local (in this case, Canadian provincial) curricula. At the same time, this certainty diminishes as questions about the IBDP curriculum become more specific. This suggests the existence of a dominant or hegemonic discourse surrounding the IBDP, one that presents the view that the IBDP not only produces students who excel academically and socially, but also guarantees retention and degree completion, and that IBDP students secure the highest-paying jobs upon graduation. This makes the recruitment of IBDP students an attractive financial prospect for fund-starved universities, for whom student retention is a key determinant of the level of funding they receive from the provincial government. Universities in Canada have been "tripping over each other trying to entice IB students to come to [their] institutions" (Loat, 2007) because of what appears to be a widely held view that the IBDP produces "great students" (Loat, 2007) and is an "excellent predictor of success" (Piper, 2006, p. 2).

The views and perceptions that arise from this discursive representation also have implications for education policy and the issue of equal access to publicly funded education across the country. Adoption of the IBDP in high schools raises questions about why scarce provincial funds are being spent on a program that benefits a select few, rather than being used to benefit entire schools and to further strengthen Canada's already world-class education system. In addition, because of the high cost of running the IBDP, parents are often required to pay fees, meaning that only those who can afford it have the opportunity (W. Baker, 2014). Thus, the implication of the IBDP is that "public education" is becoming more exclusive, made up of insiders and outsiders. 


\section{Notes}

1 The International Baccalaureate Diploma Program is referred to inconsistently in the literature as "IBDP," “DP," "IB," “IBD,” "IBP,” or "IB DP.” Here, the diploma program is referred to as "IBDP," except in quotations that have other usage; "IB" is used to refer to the IBO's whole system of education.

2 The UK study targeted pro-vice-chancellors (Jenkins, 2003, p. 7) and, according to Coates et al. (2007), the Australia/NZ study "specifically targeted 'senior university representatives.' The views are therefore of people working in decision-making capacities within universities, and may not necessarily be the same as those [of] people who have routine operational involvement with the IB Diploma or other senior secondary qualifications" (p. 8).

3 In the Australia/NZ survey (2007), one participant referred to this issue: "In my view IB students are very self-confident and self-motivated, with a broader view of the world ... they have been high performers. I suspect that students like this select the IB, not that the IB produces students like this" (p. 44).

4 According to the IB Learner Profile published by the IBO, IB students are (i) inquirers; (ii) knowledgeable; (iii) thinkers; (iv) communicators; (v) principled; (vi) openminded; (vii) caring; (viii) risk-takers; (ix) balanced; and (x) reflective (IBO, 2016).

\section{Acknowledgements}

Many thanks to Dr. Michael Fitzgerald for his very helpful feedback in the writing of this article. I am also deeply thankful to all the admissions personnel for their participation. This study would not have been possible without them. I would also like to thank the three anonymous reviewers for their valuable comments and suggestions in helping to improve this article.

\section{References}

Amuedo-Dorantes, C., Mach, T., \& Clapp, J. D. (2004). The impact of schools on juvenile substance initiation and use. Prevention Science, 5(2), 91-99.

Bagnall, N. F. (1994). The International Baccalaureate in Australia and Canada: 1980-1993 (Unpublished doctoral dissertation). University of Melbourne, Melbourne, Australia.

Bagnall, N. F. (2010). Education without borders: Forty years of the International Baccalaureate, 19702010. Saarbrücken, Germany: VDM Verlag Dr Muller.

Baker, P. (2005). Public discourses of gay men. London, UK: Routledge.

Baker, P. (2006). Using corpora in discourse analysis. London, UK: Continuum.

Baker, P. (2010). Sociolinguistics and corpus linguistics. Edinburgh, UK: Edinburgh University Press.

Baker, P., Gabrielatos, C., KhosraviNik, M., Krzyżanowski, M., McEnery, T., \& Wodak, R. (2008). A useful methodological synergy? Combining critical discourse analysis and corpus linguistics to examine discourses of refugees and asylum seekers in the UK press. Discourse \& Society, 19(3), 273-306. 
Baker, W. (2014). "Curricular choice” in Ontario public secondary schools: Exploring the policy and practice of the International Baccalaureate Diploma Programme (Unpublished master's thesis). The University of Western Ontario, Toronto, Canada.

Barnes, R. (2004). Perceptions of the International Baccalaureate Programme. IB Research Notes, 4(1), 2-4.

Blackburn, R. (1991). The International Baccalaureate: A curriculum at upper secondary level and a university entrance examination. In P. Jonietz \& D. Harris (Eds.), World yearbook of education 1991: International schools and international education (pp. 6-14). London, UK: Kogan Page.

Brown, J. D. (2001). Using surveys in language programs. Cambridge, UK: Cambridge University Press.

Bunnell, T. (2008). The global growth of the International Baccalaureate Diploma Programme over the first 40 years: A critical assessment. Comparative Education, 44(4), 409-424.

Bunnell, T. (2010). The International Baccalaureate and a framework for class consciousness: The potential outcomes of a "class-for-itself." Discourse: Studies in the Cultural Politics of Education, 31(3), 351-362.

Bunnell, T. (2011). The International Baccalaureate in the United States: From relative inactivity to imbalance. The Educational Forum, 75, 66-79.

Bunnell, T. (2014). The International Baccalaureate and its "second era" of ambitious rhetoric: Wider access and greater impact. In D. P. Hobson \& I. Silova (Eds.), Globalizing minds: Rhetoric and realities in international schools (pp. 137-157). Charlotte, NC: Information Age Publishing.

Byrd, S., Ellington, L., Gross, P., Jago, C., \& Stern, S. (2007). Advanced Placement and International Baccalaureate: Do they deserve gold star status? Washington, DC: Thomas B. Fordham Institute. Retrieved from http://edex.s3-us-west-2.amazonaws. com/publication/pdfs/APIB_9_o.pdf

Cambridge, J. (2002). Response to Judy Hinrichs' article. IB Research Notes, 2(1), 11. Retrieved from https://web.archive.org/web/20110105235113/http://www.ibo.org/ programmes/research/publications/documents/notesfebruary02.pdf

Cambridge, J. (2008). A review of research relating to the IB Diploma Programme. Retrieved from http://www.ibo.org/globalassets/publications/ib-research/dpresearch review-1.pdf

Coates, H., Rosicka, C., \& MacMahon-Ball, M. (2007). Perceptions of the International Baccalaureate Diploma Programme among Australian and New Zealand universities. Retrieved from http://www.ibo.org/contentassets/d1coaccb5b804676ae9e782b78c8bc1c/ iboperceptionsreportfinal.pdf

Conner, J. O. (2008). From international schools to inner-city schools: The first principles of the International Baccalaureate Diploma Program. Teachers College Record, $110(2), 322-351$. 
Daly, K. (2012). An exploration of Virginia law on recognition, university officials, and perceptions of the International Baccalaureate Diploma Programme (Unpublished doctoral dissertation). George Mason University, Fairfax, USA.

Doherty, C. (2009). The appeal of the International Baccalaureate in Australia's educational market: A curriculum of choice for mobile futures. Discourse: Studies in the Cultural Politics of Education, 30(1), 73-89.

Doherty, C., Luke, A., Shield, P., \& Hincksman, C. (2012). Choosing your niche: The social ecology of the International Baccalaureate Diploma in Australia. International Studies in Sociology of Education, 22(4), 311-332.

Fairclough, N., \& Wodak, R. (1997). Critical discourse analysis. In T. A. van Dijk (Ed.), Discourse as social interaction (pp. 258-284). London, UK: Sage.

Fitzgerald, S. (2015). Perceptions of the International Baccalaureate (IB) in Ontario universities. Canadian Journal of Education, 38(3), 1-34.

Fox, E. (1998). The emergence of the International Baccalaureate as an impetus for curricular reform. In M. C. Hayden \& J. J. Thompson (Eds.), International education: Principles and practice (pp. 65-76). London, UK: Kogan Page.

Frank-Gemmill, G. (2013). The IB Diploma and UK university degree qualifications. Journal of Research in International Education, 12(1), 49-65.

Gardner-McTaggart, A. (2016). International elite, or global citizens? Equity, distinction and power: The International Baccalaureate and the rise of the South. Globalisation, Societies and Education, 14(1), 1-29.

Gehring, J. (2001). The International Baccalaureate: "Cadillac" of college-prep programs. Education Week, 2O(32), 19. Retrieved from http://www.edweek.org/ew/ articles/2001/04/25/32ib.h20.html

Green, F., \& Vignoles, A. (2012). An empirical method for deriving grade equivalence for university entrance qualifications: An application to A levels and the International Baccalaureate. Oxford Review of Education, 38(4), 473-491.

Halic, O. (2013). Postsecondary educationalattainment of IB diploma candidates from US high schools. International Baccalaureate Organization. Retrieved from http://www. ibo.org/globalassets/publications/ib-research/dp/nscpostsecondaryfullreportfinal.pdf

Hayden, M. C., \& Wong, C. S. D. (1997). The International Baccalaureate: International education and cultural preservation. Educational Studies, 23(3), 349-361.

Higher Education Statistics Agency (HESA). (2011). International Baccalaureate students studying at UK higher education institutions: How do they fare? Retrieved from http://www.ibo.org/contentassets/d74675437b4f4ab38312702599a432f1/hesaukpost sec_final_report.pdf

Hoey, M. (2005). Lexical priming: A new theory of words and language. London, UK: Routledge.

International Baccalaureate Organization. (2003). 2003 Canadian survey of high school seniors participating in the International Baccalaureate Program. Retrieved from: https://www.ibo.org/ibna/research/documents/2003StudentSurvey.Canada.pdf 
International Baccalaureate Organization.(2007).IBDiploma Programme: Aguidefor universities and colleges. Retrieved from https://web.archive.org/web/20130117051410/ https://www.ibo.org/communications/publications/documents/e_uni_recognition_ brochure_07.PDF

International Baccalaureate Organization. (2015). University admissions officers suggest DP as best preparation for workplace and university. Retrieved from http:// www.ibo.org/en/news/news-about-the-ib/university-admissions-officers-suggest-dpas-best-preparation-for-workplace-and-university/

International Baccalaureate Organization. (2016). The IB learner profile. Retrieved from http://www.ibo.org/en/benefits/learner-profile/

James, K. (2005). International education: The concept, and its relationship to intercultural education. Journal of Research in International Education, 4(3), 313-332.

Jenkins, C. (2003). Perceptions of the International Baccalaureate Diploma Programme.Retrievedfromhttp://www.ibo.org/contentassets/d1coaccb5b804676aege7 82b78c8bc1c/jenkinsukperceptions.pdf

Loat, W. (2007). Bridging the gap: The IB program as university preparation. AACRAOSEM Newsletter. American Association of Collegiate Registrars and Admissions Officers. Retrieved from https://web.archive.org/web/20141101175801/http://www4.aacrao. org:8o/semsource/sem/index6861.html?fa=print\&id=3697

Mathews, J., \& Hill, I. (2005). Supertest: How the International Baccalaureate can strengthen our schools. Chicago, IL: Open Court.

Matthews, M. (1989). The scale of international education. International Schools Journal, 17, 7-17.

May, H., \& Perna, L. (2011). A longitudinal analysis of student and school diversity in the International Baccalaureate (IB) diploma program in the U.S. Paper presented at the Annual Meeting of the American Educational Research Association, New Orleans. Retrieved from http://www.cpre.org/sites/default/files/meetingpaper/1373_aera2011ib. pdf

Mayer, A. P. (2006). Interrupting social reproduction: The implementation of an International Baccalaureate Diploma program in an urban high school (Unpublished doctoral dissertation). University of California - Davis, Davis, CA.

O'Connor, R. P. (2011). Raising all boats? An examination of claims that the International Baccalaureate diploma program is good for all (Unpublished doctoral dissertation). University of Iowa, Iowa City, IA.

Panich, C. (2001). A study of the university performance of students with International Baccalaureate high school experience (Unpublished doctoral dissertation). Duquesne University, Pittsburgh, PA.

Parker, W. C. (2011). "International education” in US public schools. Globalisation, Societies and Education, 9(3), 487-501. 
Perna, L. W., May, H., Yee, A., Ransom, T., Rodriguez, A., \& Fester, R. (2011). The potential role of the International Baccalaureate (IB) Diploma Programme in improving academic preparation for college for all students. Paper presented at the Annual Meeting of the Association for the Study of Higher Education, Charlotte, North Carolina. Retrieved from http://www.cpre.org/sites/default/files/meetingpaper/1372_ ashe2011-ibpaper1232011.pdf

Peterson, A. D. C. (1987). Schools across frontiers: The story of the International Baccalaureate and the United World Colleges. La Salle, IL: Open Court.

Piper, M. (2006). Universities and the IBO: Your mission is our mission. Peterson Lectures, International Baccalaureate Organization. Retrieved from https://web.archive. org/web/20130603195906/https://www.ibo.org/council/peterson/piper/documents/ piper_lecture.pdf

Pook, G. (2009). External examinations beyond national borders: The International Baccalaureate. In B. Vlaardingerbroek \& N. Taylor (Eds.), Secondary school external examination systems: Reliability, robustness and resilience (pp. 319-336). Amherst, NY: Cambria Press.

Reisigl, M., \& Wodak, R. (2001). Discourse and discrimination: Rhetorics of racism and antisemitism. London, UK: Routledge.

Resnik, J. (2012). The denationalization of education and the expansion of the International Baccalaureate. Comparative Education Review, 56(2), 248-269.

Richardson, J. E., \& Wodak, R. (2009). Recontextualising fascist ideologies of the past: Right-wing discourses on employment and nativism in Austria and the United Kingdom. Critical Discourse Studies, 6(4), 251-267.

Rowell, P. M. (1983). Planning for the implementation of the International Baccalaureate Program: A situational study (Unpublished doctoral dissertation). University of Alberta, Edmonton, AB.

Spahn, B. A. (2001). America and the International Baccalaureate-implementing the International Baccalaureate in the United States: A study of three schools. Suffolk, UK: John Catt Educational.

Stubbs, M. (2001). Texts, corpora and problems of interpretation: A response to Widdowson. Applied Linguistics, 22(2), 149-172.

Tarc, P. (2009). Global dreams, enduring tensions: International Baccalaureate program in a changing world. New York, NY: Peter Lang.

Tarc, P., \& Beatty, L. (2012). The emergence of the International Baccalaureate Diploma in Ontario: Diffusion, pilot study and prospective research. Canadian Journal of Education, 35(4), 341-375.

Tarver, E. T. (2010). University admissions officers' perceptions of student performance within the International Baccalaureate Diploma Program (Unpublished doctoral dissertation). Louisiana State University, Baton Rouge, LA.

Verneuille, J. T. (2011). The potential impacts of implementing the International Baccalaureate program in the Sag Harbor Union Free School district (Unpublished master's thesis). State University of New York, New York, NY. 
Vogt, W. P. (2007). Quantitative research methods for professionals. Boston, MA: Pearson.

Walker, G. (2005, July 9). Looking back and looking forward: The next 30 years. Plenary address to the IBNA Annual Regional Conference, Montréal, QC. Retrieved from https://web.archive.org/web/20070930201614/http://www.ibo.org/dg/emeritus/ speeches/documents/ibna_julo5.pdf

Weenink, D. (2008). Cosmopolitanism as a form of capital: Parents preparing their children for a globalizing world. Sociology, 42(6), 1089-1106.

Whitehead, K. (2005). Advertising advantage: The International Baccalaureate, social justice and the marketisation of schooling. Paper presented at the Australian Association for Research in Education Annual Conference, University of Western Sydney, Parramatta, Australia. Retrieved from http://www.aare.edu.au/data/publications/2005/ whio5426.pdf

Wodak, R. (2001). The discourse-historical approach. In R. Wodak \& M. Meyer (Eds.), Methods of critical discourse analysis (pp. 63-94). London, UK: Sage.

Wodak, R. (2007). Pragmatics and critical discourse analysis. Pragmatics \& Cognition, 15(1), 203-225.

\section{Contact Information}

Saira Fitzgerald

School of Linguistics and Language Studies

Carleton University

saira_fitzgerald@carleton.ca

Saira Fitzgerald has recently completed her doctorate at Carleton University's School of Linguistics and Language Studies. She holds a BA (Hons.) in English and an MA in Linguistics and Applied Language Studies. She has worked in educational development in Kenya, Tanzania, Indonesia, Vietnam, the United Arab Emirates, Singapore, India, and Canada. Her doctoral research is on the discursive construction of the International Baccalaureate (IB) in Canada. She is a co-author of The power of language: How discourse influences society, 2nd ed., published by Equinox, 2017. 